\title{
Wheat Straw Mulch and Its Impacts on Three Soilborne Pathogens of Peanut in Microplots
}

\author{
Lisa M. Ferguson, Former Graduate Research Assistant, and B. B. Shew, Senior Researcher, Department of Plant \\ Pathology, North Carolina State University, Raleigh 27695
}

\begin{abstract}
Ferguson, L. M., and Shew, B. B. 2001. Wheat straw mulch and its impacts on three soilborne pathogens of peanut in microplots. Plant Dis. 85:661-667.

Experiments were conducted in 1992, 1993, and 1994 to determine the effects of surface residue on incidence of Cylindrocladium black rot (CBR), Sclerotinia blight, and Southern stem rot of peanut in microplots in North Carolina. Soil was infested with either Cylindrocladium parasiticum, Sclerotium rolfsii, or Sclerotinia minor and plots were planted with the peanut cultivars NC 7 or NC 10C. Wheat straw was applied to establish 80 to $90 \%$ soil-surface coverage. Disease incidence data were collected every 2 weeks in 1992 and weekly in 1993 and 1994. Southern stem rot incidence did not increase with straw amendment but final inoculum density of Sclerotium rolfsii was highest in straw-amended plots. Straw amendment enhanced CBR incidence in 1992, but had minimal effects in 1993 and 1994. Neither root rot severity nor inoculum density of $C$. parasiticum was affected by straw treatment. Straw application reduced Sclerotinia blight in 1992 and 1993 but not in 1994 compared with unamended plots. Initial inoculum density had the greatest impact on final Sclerotinia minor populations. Soil temperature and moisture were monitored in 1993 and 1994. Soil at 0 to $2 \mathrm{~cm}$ of depth in strawamended microplots was 1 to $2^{\circ} \mathrm{C}$ cooler than in unamended plots.
\end{abstract}

Additional keywords: Arachis hypogaea, groundnut, mulches, soil amendment

Increased interest in long-term sustainability in agricultural systems, concern for soil and water conservation, and potential increases in crop productivity have spurred research into organic soil amendments, cover crops, and other alternatives to traditional tillage. Potential benefits of maintaining cover crop residue on the soil surface include reduction in costs associated with repeated intensive tillage, improvements in weed and insect control, improvements in soil fertility and structure, prevention of erosion, and soil moisture retention (9). Residue on the soil surface decreases soil temperature and increases soil moisture (27). In addition to altering the microclimate near the soil surface, residue may influence pathogen survival and pathogenicity. Organic amendments and mulches affect soil microflora, which influence host plant growth, susceptibility, and pathogen biology (9).

Rotation of crops is an effective way to control soilborne diseases in many agricultural systems. The susceptible host is removed from cultivation and rotational crops may make conditions more favorable

Corresponding author: L. M. Ferguson

E mail: ferguson_gray@mindspring.com

Accepted for publication 2 February 2001.

Publication no. D-2001-0423-02R

(C) 2000 The American Phytopathological Society for future cycles of susceptible host growth by altering microbial populations (19). The addition of organic matter from rotational or cover crops may directly or indirectly suppress disease by enhancing production of decomposition products by antagonistic microbial populations that inhibit pathogens and enhance host growth (30). In production of peanut (Arachis hypogaea L.), burying crop residues 15 to $20 \mathrm{~cm}$ deep with a moldboard plow has been recommended as an effective means of controlling weeds and several peanut diseases, especially southern stem rot caused by Sclerotium rolfsii (31). This disease is important in all peanut-growing regions of the United States. Abundant organic substrates and high humidity in the plant canopy favor disease development (31). Although high soil moisture is associated with severe disease (31), drying and remoistening of the soil also may encourage sclerotial germination (34). Conversely, moist, cool soil under residue cover accompanied by nutrients supplied by decomposing straw may encourage parasitism and subsequent decay of sclerotia of $S$. rolfsii by biocontrol agents (34). Researchers have demonstrated reduced survival of sclerotia and mycelia in moist field soil (35). In related studies, burial of sclerotia of $S$. rolfsii at depths of 5 to $6 \mathrm{~cm}$ reduced viability of sclerotia compared to those at the soil's surface, reinforcing the arguments for clean tillage as an effective control measure for southern stem rot (35).
Results of field studies comparing severity of stem rot in conventional and reduced tillage have been inconclusive, due in part to uneven distribution of inoculum in the field (12).

Little information is available on the influence of surface mulches on Sclerotinia blight of peanut caused by Sclerotinia minor Jagger. High-residue conditions maintained on the soil surface might promote germination of $S$. minor sclerotia by increasing relative humidity and cooling soil temperatures (11). Alterations in the microclimate within the plant canopy related to plant structure have influenced disease development in several studies (4). Decaying crop residue may provide a food base for $S$. minor and may optimize soil $\mathrm{pH}$, increasing infection (16). However, these conditions may promote the growth of naturally occurring biocontrol organisms that colonize and destroy sclerotia (2).

Effects of surface mulches on Cylindrocladium black rot (CBR), caused by Cylindrocladium parasiticum, have not been studied extensively. Previous research has shown that soil moisture near field capacity and soil temperatures around $25^{\circ} \mathrm{C}$ optimize conditions for CBR development (23). Low soil moisture restricts colonization and decay of peanut roots by $C$. parasiticum and extremes in soil temperature $\left(>30\right.$ or $\left.<20^{\circ} \mathrm{C}\right)$ reduce disease severity (23). Cultural practices such as delayed planting benefit host growth and suppress CBR development by exposing plants to warmer soils (33). The addition of wheat straw to the soil surface probably does not provide a substrate for growth of $C$. parasiticum (25) but may lead to increased nodulation of the peanut root system in response to $\mathrm{N}$ immobilization, increasing susceptibility to CBR (14). Reductions in CBR root rot severity have been related to altered soil microflora composition resulting from the use of different rotational crops (6). The addition of wheat straw may have a wide range of effects on this hostpathogen system.

Studies conducted in 1992, 1993, and 1994 evaluated wheat straw amendment to the soil surface and the incidence and severity of disease as well as subsequent changes in inoculum density of Sclerotium rolfsii, Sclerotinia minor, and C. parasiticum. Changes in microclimate caused by straw amendment were also investigated. Microplot studies were designed to evaluate the effect of surface debris or mulches 
on disease by excluding effects of soil preparation.

\section{MATERIALS AND METHODS}

Plot establishment. Microplots $(76 \mathrm{~cm}$ in diameter) were established at the North Carolina State University (NCSU) Central Crops Research Station at Clayton (5). All microplots were fumigated with metam sodium (active ingredient, sodium methyldithiocarbamate, at $142 \mathrm{~kg} / \mathrm{ha}$ ) in May 1992 before studies were initiated. All plots were tilled by hand and were supplemented with granular Bradyrhizobium at 5 $\mathrm{g} / \mathrm{kg}$ of soil (cowpea cross-inoculation group; Nitragin Co. Goldsboro, NC) prior to planting in June 1992. Microsclerotia of C. parasiticum Crous, Wingefield, and Alfenas were added to plots before planting as described below. Germinated peanut seed (10 to 12 seeds) was planted in each microplot in early June of each year (I June 1992, 4 June 1993, and 10 June 1994). The Virginia-type peanut cultivars $\mathrm{NC} 7$, susceptible to CBR, and NC 10C, moderately resistant to $\mathrm{CBR}$, were used in all experiments $(37,38)$. Approximately $500 \mathrm{~g}$ of wheat straw was applied (10 June 1992, 14 June 1993, and 18 June 1994) to the surface of half of the plots, providing approximately 80 to $90 \%$ coverage of the soil surface. Other plots were maintained with a clean soil surface. Plants were thinned to four plants per plot 2 to 3 weeks after planting. Standard production practices, including applications of chlorothalonil and gypsum, were used in all plots (3). At harvest, plants were dug and inverted for final disease ratings. Plants then were removed from plots and discarded. Mi-
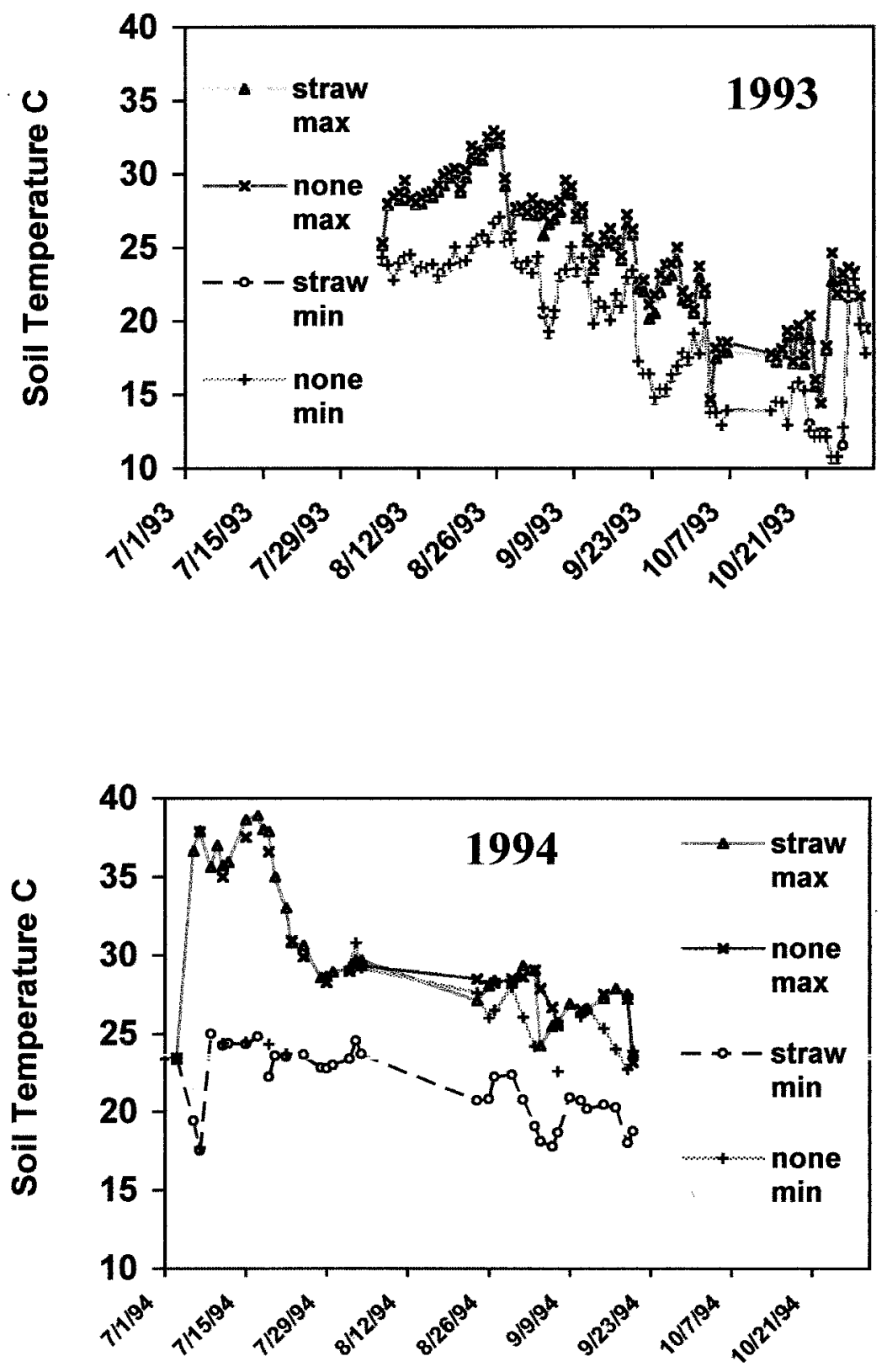

Fig. 1. Effects of wheat straw mulch on soil temperatures. Daily maximum and minimum soil temperatures at depths of $2 \mathrm{~cm}$ are shown in 1993 and 1994.

croplots were fallow after harvest through the fall and winter. In straw-amended plots, straw remained on the soil surface until spring. Prior to planting in each season, all plots were hand tilled to a depth of 25 to $30 \mathrm{~cm}$. Fresh straw mulch was added to amended microplots in each year of the study.

Inoculum production and soil infestation. Microsclerotia-mycelium suspensions were prepared from a collection of seven isolates of $C$. parasiticum originally obtained from infected peanut. Isolates were grown on potato-dextrose agar (PDA) for 6 weeks, blended in water, and sieved through 74- and 840- $\mu \mathrm{m}$ nested sieves. Microsclerotia retained on the $74-\mu \mathrm{m}$ sieve were used to infest soil in selected microplots in early June 1992 (24). High inoculum density (ID) plots were infested at 20,000 microsclerotia (ms) per kilogram of soil and low-ID plots at $2,000 \mathrm{~ms} / \mathrm{kg}$ by uniformly mixing soil in plots to a depth of 25 to $30 \mathrm{~cm}$. Microsclerotia in high-ID treatments were supplemented in 1993 to reestablish a level of $20,000 \mathrm{~ms} / \mathrm{kg}$ in plots assayed at levels less than $18,000 \mathrm{~ms} / \mathrm{kg}$. In 1994, preplant inoculum levels of $C$. parasiticum had not dropped below initial infestation levels and so were not adjusted.

A culture of Sclerotinia minor Jagger, from peanut, was grown on sterilized oat grains for maintenance. To produce sclerotia for this study, colonized oat grains were transferred to PDA and incubated for 15 to 20 days. Sclerotia produced on these cultures were air dried on the agar surface. $S$. minor sclerotia were then collected, screened to separate clusters of sclerotia and standardize size (range, 0.5 to $2 \mathrm{~mm}$ ), and subsampled to estimate viability by plating on PDA. Microplots were infested at 2 sclerotia/ $\mathrm{kg}$ of soil ( 25 sclerotia/plot) and 8 sclerotia/kg of soil (100 sclerotia/plot) in July 1992. This ID is based on surface area per plot and concentration of the pathogens to a depth of $2.5 \mathrm{~cm}$.

A peanut isolate of Sclerotium rolfsii Sacc. was grown on sterilized oat grains and sclerotia were produced by incubating colonized oat grains on moistened nonsterile soil (31). Sclerotia were harvested, air dried, and screened to separate clusters of sclerotia and standardize sclerotia by size (range, 0.5 to $2 \mathrm{~mm}$ ). Viability was assayed by surface-disinfesting $(0.5 \%$ sodium hypochlorite for $1 \mathrm{~min}$ ) and plating sclerotia on PDA. Plots were infested in July 1992 at 25 sclerotia/plot (2 sclerotia/kg of soil) and 100 sclerotia/plot $(8$ sclerotia $/ \mathrm{kg}$ of soil). Sand was mixed with sclerotia to aid in even dispersal of inoculum on the soil surface. Due to low disease incidence in 1992, Sclerotinia minor- and Sclerotium rolfsii-infested plots were reinfested in July 1993 with the equivalent of 25 and 100 viable sclerotia per plot for the low- and high-ID treatments.

Experimental design. Microplot experiments were established in a factorial 
treatment design of two levels of straw (presence or absence), two cultivars (NC 7 or NC 10C), and two IDs for each pathogen. Each pathogen was evaluated in a separate experiment of the same design. Four control treatments consisted of combinations of two levels of straw and two cultivar combinations, without inoculum. The treatments were replicated nine times in a randomized complete block design. Treatments were reestablished in the same plots each year for three consecutive years of the study.

Disease ratings. Disease incidence was monitored every 2 weeks in 1992 and weekly in 1993 and 1994. Incidence was based on characteristic aboveground symptoms of each disease and signs of each pathogen (18). Numbers of plants per plot with one or more limbs showing symptoms characteristic of each disease were recorded at each assessment date.

In October 1994, at the termination of microplot experiments, plants were dug and roots in the CBR experiment were rated for root rot severity. Root rot characteristic of $C$. parasiticum was assessed on a 0 -to- 5 scale, where $0=$ no lesions and $5=$ completely decayed (28).

Soil temperature and moisture monitoring. In 1993 and 1994, soil temperature and moisture (matric potential) were monitored in the center of 10 microplots. Temperature sensors (model 107B; Campbell Scientific, Logan, UT) were placed in each of five straw-covered and five unmulched microplots at 2-cm depths. Delmhorst soil moisture blocks (model 223; Campbell Scientific) also were positioned in the center of these microplots, and each was buried in soil at depths of $2 \mathrm{~cm}$ to record changes in soil moisture during the growing season. Soil temperature and moisture (matric potential) were recorded at hourly intervals by a Campbell Scientific CR21X Micrologger. Daily average, maximum, and minimum soil temperature and moisture values were programmed for output by the CR21X.

Pathogen assays. Population densities of $C$. parasiticum were determined prior to planting each year and postharvest in 1993 and 1994. Ten soil cores (15 cm deep by 2 $\mathrm{cm}$ in diameter) were taken from each microplot, bulked, and mixed. Samples of approximately $300 \mathrm{~g}$ were stored in sealed plastic bags at $25^{\circ} \mathrm{C}$ until assayed. Assays for C. parasiticum microsclerotia were conducted on $200 \mathrm{~g}$ of soil per microplot according to procedures described by Phipps and Beute (22).

Final populations of $S$. rolfsii were determined from soil samples collected on 20 October 1994. A 14-by-21-cm soil scoop was used to collect samples to a depth of 3 $\mathrm{cm}$ in each plot. Approximately $1.5 \mathrm{~kg}$ of soil per plot was collected and mixed, and air-dried soil samples were stored in closed plastic bags at room temperature until assayed. Samples were screened through a 2- $\mathrm{mm}$ sieve and assayed for viable sclerotia using a method devised by Shew and Beute (31).

Assays for populations of Sclerotinia minor were conducted at the completion of experiments in Oct 1994. Soil samples were collected using a 14-by-21-cm soil scoop at to a depth of $3 \mathrm{~cm}$ in each plot. One kilogram of soil was mixed and stored in closed plastic bags at 4 to $5^{\circ} \mathrm{C}$ until assayed. Prior to assay, samples were air dried and screened through a 2-mm sieve, after which four $100-\mathrm{g}$ subsamples from each plot were assayed. Samples were processed in a semiautomatic elutriator and S. minor sclerotia were subsequently counted and assessed for viability according to procedures used by Porter and Steele (26).

Data analysis. Disease incidence and area under disease progress curve (AUDPC) data from each year were analyzed individually (29). Plots with no symptomatic plants were assigned a value of 0 and plots with 1 or more diseased plants a value of 1 for disease incidence analysis. Analysis of variance (ANOVA) was used to determine significant effects on disease incidence among the experimental factors. Uninoculated checks were excluded from all ANOVAs. In analysis of AUDPC, all non-zero data were examined. In plots showing 1 or more diseased plants, counts of diseased plants per plot were used to calculate AUDPC. Data for each disease from the 1992, 1993, and 1994 experiments also were combined for analysis in order to examine trends in experimental effects through the 3 years of our study. Incidence and AUDPC data were examined using a factorial treatment structure and interactions with year were evaluated. Square root transformation was used on ID data. ID for $C$. parasiticum was analyzed across seasons. Repeated measures analyses were used to determine effects of time on changes in ID. Spearman's rank correlation tests were used to evaluate the relationship of CBR incidence and AUDPC to preseason ID of $C$. parasiticum. Final IDs of Sclerotium rolfsii and Sclerotinia minor and root rot ratings of $C$. parasiticum-infected plants (based on a 0to-5 scale) were analyzed by ANOVA.

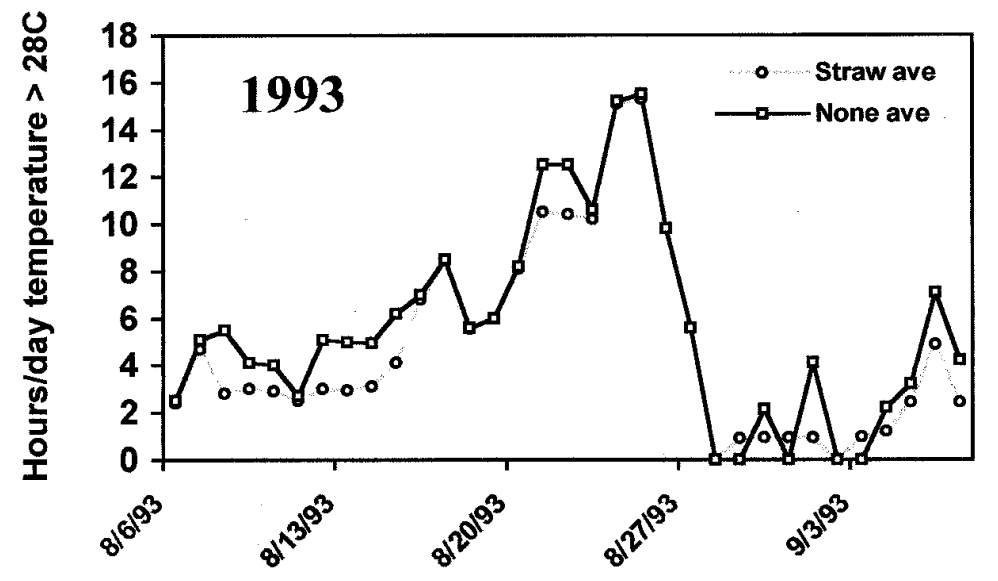

Fig. 2. Straw effects on duration of soil temperatures exceeding $28^{\circ} \mathrm{C}$ in 1993.

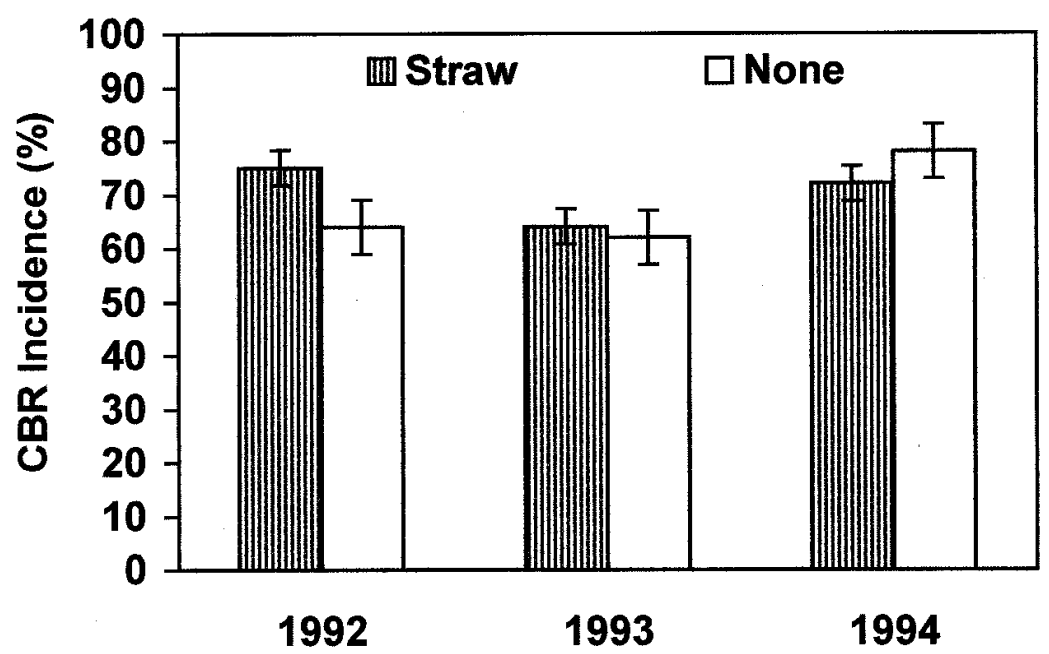

Fig. 3. Effects of wheat straw mulch on final incidence of Cylindrocladium black rot (CBR) of peanut. Amendment effects in each year were not significant $(P>0.05)$. 
Daily maximum and minimum soil temperatures and moisture levels in 1993 and 1994 in straw-amended plots and nonamended plots were analyzed by ANOVA.

\section{RESULTS}

Microclimate changes related to straw amendment. Maximum and minimum soil moisture (matric potential) was monitored from 5 August to 25 October 1993 and from 26 July to 23 September 1994. No statistically significant differences in mean soil moisture were noted between strawcovered and bare-soil microplots. In general, in 1994, soil moisture content re- mained at higher, more constant levels than in 1993. Nonamended plots generally had lower soil moisture than straw-amended plots. In 1993, soil moisture ranged from saturation at $0 \mathrm{kPa}$ to a minimum value of $-5.0 \times 10^{-8} \mathrm{kPa}$. Fluctuations in soil moisture occurred at several time points during the growing season, with a more typical range between 0 and $-2.0 \times 10^{-8} \mathrm{kPa}$. Soil moisture in 1994 fluctuated less frequently and soil remained moister than in plots monitored in 1993. Water potential values ranged between saturation at $0 \mathrm{kPa}$ to a minimum of $-1.0 \times 10^{-8} \mathrm{kPa}$ in 1994 and dried to levels greater than $-3.0 \times 10^{-9} \mathrm{kPa}$

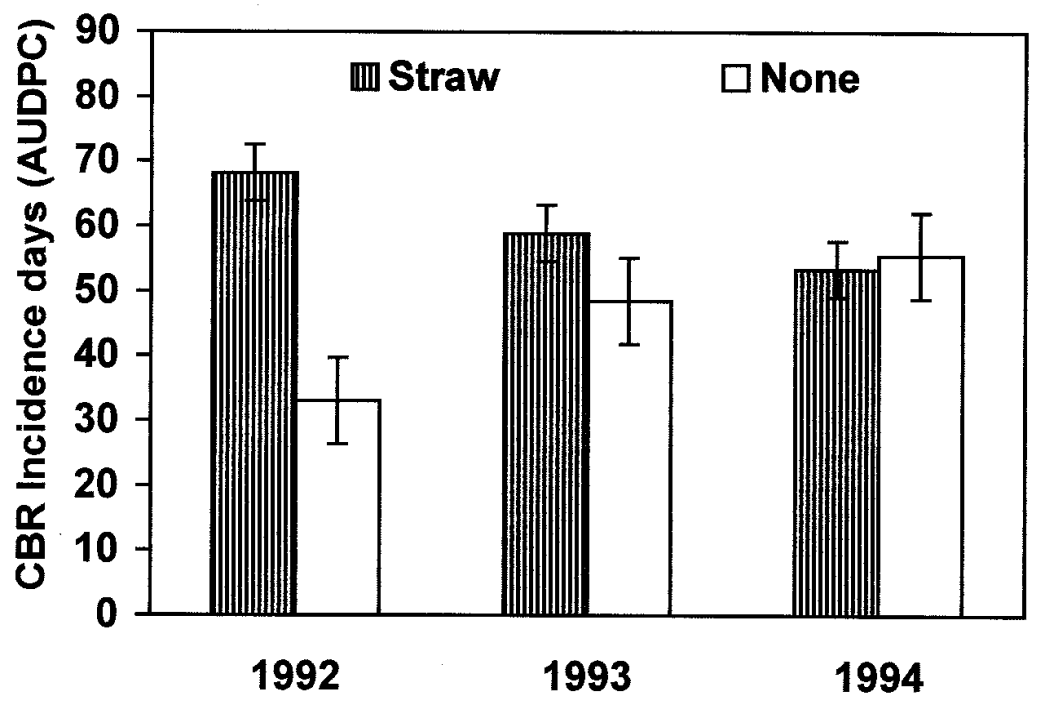

Fig. 4. Effects of wheat straw mulch on area under disease progress curve (AUDPC) for Cylindrocladium black rot of peanut. Amendment effects were significant in $1992(P \leq 0.057)$, but not in 1993 or $1994(P>0.05)$.

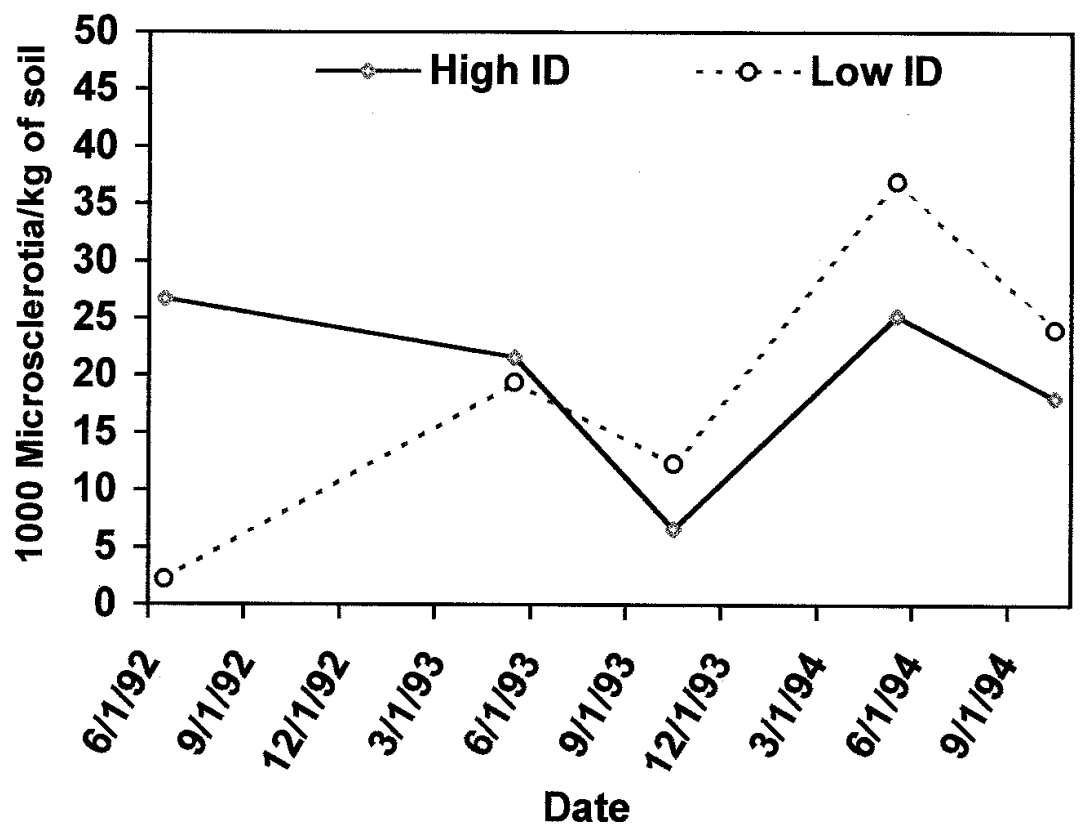

Fig. 5. Inoculum density (ID) (in microsclerotia[ms]/kilogram of soil) of Cylindrocladium parasiticum in plots initially infested with 20,000 ms/kg (high ID) or 2,000 ms/kg (low ID) in June 1992 and sampled through October 1994. Additional inoculum was added to selected high inoculum density plots in May 1993.

only three times during the growing season.

Soil temperatures at depths of $2 \mathrm{~cm}$ were measured in microplots from 5 August to 31 October 1993 and from 4 July to 24 September 1994 (Fig. 1). Due to missing data points, we were unable to test significance of differences among amendment treatments in 1994. Discussion of maximum and minimum soil temperatures affected by straw mulch will be limited to 1993 data alone, although 1994 data is plotted for comparison. Straw amendment did not significantly affect minimum soil temperatures in 1993 (Fig. 1). Minimum soil temperatures in August 1993 ranged from 22 to $27^{\circ} \mathrm{C}$. In September, minimum temperatures ranged from 15 to $25^{\circ} \mathrm{C}$. Low temperatures in October measured from 12 to $23^{\circ} \mathrm{C}$.

Maximum soil temperatures in strawamended plots were significantly lower than those in nonamended plots on several dates in 1993, although differences were seldom greater than $1^{\circ} \mathrm{C}$ (Fig. 1). Greatest differences in soil temperature were noted between 30 August and 6 September and 18 to 25 September. In 1993, mean duration of daily temperatures above $28^{\circ} \mathrm{C}$ was reduced by as much as $2 \mathrm{~h} /$ day in strawamended plots (Fig. 2). Soil and ambient temperatures in 1994 were more moderate than temperatures measured during the same time period in 1993 (Fig. 1).

Cylindrocladium black rot. Presence of wheat straw amendments did not consistently affect CBR incidence, AUDPC, root rot ratings, or ID in each year of this study. In combined analysis over 3 years of studies, no interactions of other treatments with straw amendment were found (Figs. 3 and 4). Data analysis on an individual year basis revealed a marginally significant straw effect $(P \leq 0.0569)$ on AUDPC in 1992 alone (Fig. 4). Effects of cultivar on CBR incidence depended on year; the cultivar-year interaction was significant at $P$ $\leq 0.0532$. Final disease incidence on the CBR-susceptible cultivar NC 7 increased each year from $69 \%$ in 1992 , to $77 \%$ in 1993 , and finally to $92 \%$ in 1994 . In 1992 , there were no differences in incidence between NC 7 and NC 10C but, in 1993 and 1994, final incidence of CBR on NC 7 was significantly greater than on NC $10 \mathrm{C}$. Final mean disease incidence on NC 10C was $49 \%$ in 1993 and $58 \%$ in 1994.

Densities of microsclerotia differed significantly between initial ID treatments over time (Fig. 5). Differences in ID between plots initially infested at 2,000 and $20,000 \mathrm{~ms} / \mathrm{kg}$ were found postharvest in $1993(P \leq 0.0004)$ and preharvest in 1994 $(P \leq 0.0467)$. IDs decreased during the first two field seasons in plots initially infested at high ID from original levels of 23,000 to $34,000 \mathrm{~ms} / \mathrm{kg}$ in June 1992 to $7,500 \mathrm{~ms} / \mathrm{kg}$ of soil in October 1993. Microsclerotia in high-ID treatments were supplemented in June 1993 to reestablish a level of 20,000 
$\mathrm{ms} / \mathrm{kg}$ of soil in plots assayed at levels less than $18,000 \mathrm{~ms} / \mathrm{kg}$. By spring 1994, microsclerotial densities in these plots had increased to 22,000 to $26,000 \mathrm{~ms} / \mathrm{kg}$ of soil. Inoculum levels in plots initially infested at low ID increased from 2,000 to $3,000 \mathrm{~ms} / \mathrm{kg}$ of soil in June 1992 to $14,000 \mathrm{~ms} / \mathrm{kg}$ of soil postharvest 1993, and increased to 35 to $55,000 \mathrm{~ms} / \mathrm{kg}$ of soil by October 1994 .

In a combined analysis of all three years' data, the effects of initial ID on AUDPC for CBR depended on cultivar (cultivarID, $P \leq 0.014$ ). ID did not influence AUDPC on NC 10C; however, with the susceptible cultivar $\mathrm{NC} 7$, the highest levels of disease occurred in plots that initially received low inoculum but resulted in higher final ID (Fig. 5). In those plots, mean AUDPC in low-ID plots reached 80, compared with high-ID plots with AUDPC of 40.

Cultivars differed in root rot rating taken in the fall of $1994(P \leq 0.0015)$; NC 7 had more severe root rot than NC $10 \mathrm{C}$. There was no significant main effect of straw or initial ID on root rot rating, but there was a significant cultivar-ID interaction. On NC 7 , roots were more severely rotted in plots that initially received low IDs, whereas mean root rot severity on the cultivar NC 10C did not differ with initial ID.

Final ID of $C$. parasiticum was higher in plots planted with NC 7 than with NC 10C at the conclusion of our experiments, but these differences were not significant. Straw and cultivar treatments did not significantly affect ID in any year.

Southern stem rot. Amendment with wheat straw did not affect southern stem rot incidence or AUDPC in any year of the study. However, straw amendment did influence final ID of Sclerotium rolfsii after 3 years of continuous peanut in fall of 1994 (Table 1). A significant interaction of straw-cultivar-initial ID $(P \leq 0.0076)$ occurred at the end of the experiment in 1994. More sclerotia were recovered in straw-amended NC 7 plots than in nonamended plots at high initial ID, but fewer sclerotia were noted in straw-amended NC 7 plots at low ID compared with nonamended plots (Table 1). Significant differences in AUDPC between straw treatments were not found in plots of NC 10C.

Cultivar and initial ID did not affect southern stem rot incidence in any year (Table 2). AUDPC for southern stem rot was affected by year and cultivar, with highest AUDPC in 1993 on NC 7 (Table 2 ). Final IDs of $S$. rolfsii reached their highest levels in NC 7 plots compared with NC 10C (Table 1). However, incidence and AUDPC of southern stem rot was low in 1992 and 1994 regardless of cultivar.

In control plots, which we did not infest with any of the pathogens under study, Southern stem rot symptoms and signs of S. rolfsii were found in 4 of 18 strawamended plots in 1992 and 1993 and 2 of 18 unamended plots in 1993. In 1994, no
Southern stem rot was found in control found in previous seasons. No evidence of other diseases was found in control plots. There was no evidence that germinated seeds planted in microplots harbored $C$. parasiticum, Sclerotinia minor, or Sclerotium rolfsii.

Sclerotinia blight. Straw amendment and ID had significant effects on the incidence of Sclerotinia blight over the 3-year study (Fig. 6). Straw residue suppressed Sclerotinia blight incidence at high IDs of plots, including those in which it was

Sclerotinia minor. The effects of straw amendment on disease incidence also depended on the year of the study (Fig. 7). Straw amendment dramatically reduced the numbers of infected plants in 1992 and 1993. However, disease incidence in 1994 did not differ between straw-amended and nonamended plots.

Straw amendment resulted in lower AUDPC $(P \leq 0.0097)$, particularly at high ID, as seen by the straw-ID interaction $(P$ $\leq 0.065$; Fig. 8). Mean AUDPC across years was 13.0 in the high-ID treatments

Table 1. Effects of wheat straw mulch, initial inoculum density (ID), and peanut cultivar on inoculum density of Sclerotium rolfsii

\begin{tabular}{lccc}
\hline & \multicolumn{2}{c}{ Sclerotia/kg of soila } & \\
\cline { 2 - 3 } Cultivar, treatment & Straw $^{\mathbf{b}}$ & None & Mean by cultivar \\
\hline NC 10C & & & \\
Low ID & 28.1 & 11.3 & $\ldots$ \\
High ID & 20.7 & 9.3 & $\ldots$ \\
Mean by amendment & 24.2 & 10.3 & \\
NC 7 & 19.8 & 35.3 & $\ldots$ \\
Low ID & 42 & 13.6 & $\ldots$ \\
High ID & 30.9 & 24.6 & 27.8 \\
Mean by amendment & & &
\end{tabular}

a Final inoculum density of $S$. rolfsii in infested microplots sampled October 1994.

$\mathrm{b}$ There was a significant three-way interaction of cultivar-amendment-ID $(P \leq 0.0076)$. WallerDuncan $k$-ratio tests $(k=100)$ indicated a minimum significant difference of 19.1 sclerotia of $S$. rolfsii per kilogram of soil.

Table 2. Effects of peanut cultivar on area under the disease progress curve (AUDPC) of southern stem rot caused by Sclerotium rolfsii

\begin{tabular}{lcccc}
\hline & \multicolumn{3}{c}{ Year $^{\mathbf{a}}$} & Mean \\
\cline { 2 - 4 } Cultivar & $\mathbf{1 9 9 2}$ & $\mathbf{1 9 9 3}^{\mathbf{b}}$ & $\mathbf{1 9 9 4}$ & 8.6 \\
\hline NC 10C & 1.9 & 17.1 & 6.9 & 22.6 \\
NC 7 & 3.7 & 56.8 & 8.2 & $\ldots$ \\
Mean & 2.8 & 36.6 & 7.6 & $\ldots$ \\
\hline
\end{tabular}

a The year-cultivar interaction effect on AUDPC was significant at $P \leq 0.0082$.

b Peanut cultivar influenced AUDPC in $1993(P \leq 0.0249)$.

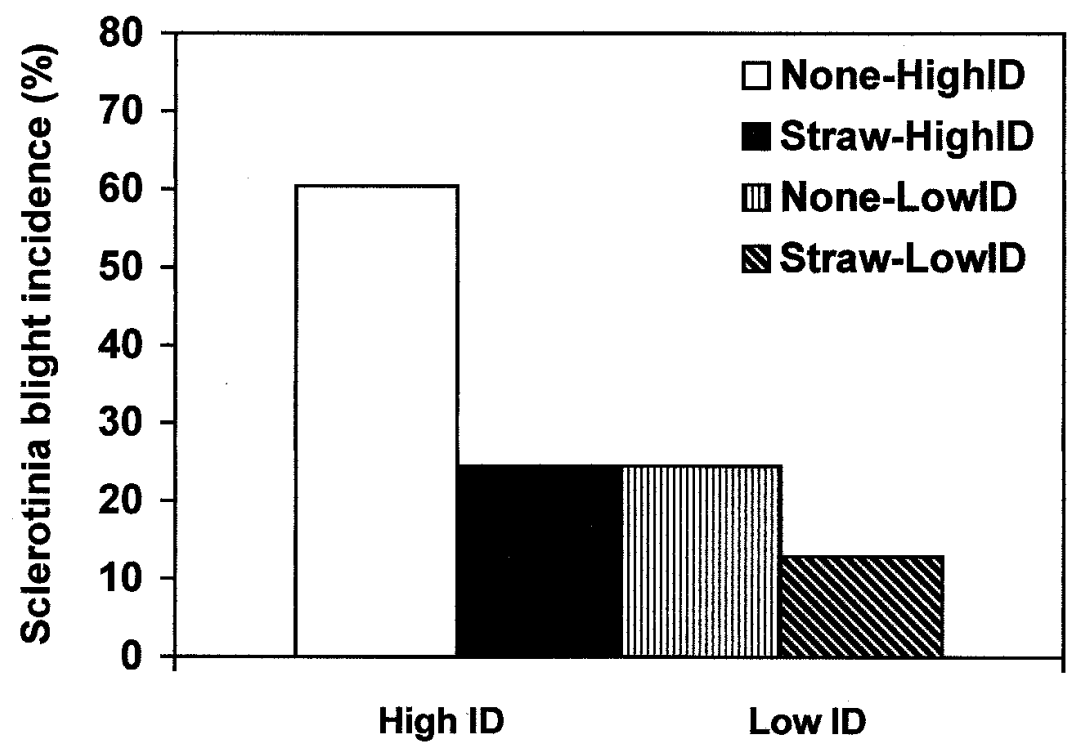

Fig. 6. Effects of wheat straw mulch and inoculum density on final incidence of Sclerotinia blight of peanut in 1992-94 growing seasons. Interaction effects of straw and initial inoculum density were significant at $P \leq 0.0351$. 
and 5.2 in low-ID treatments. ID influenced Sclerotinia blight AUDPC $(P \leq$ 0.0060).

Microplots infested initially with high numbers of sclerotia continued to have higher levels of inoculum than plots initially infested at low IDs $(P \leq 0.0218)$. Final mean ID of high-ID plots was 3.8 sclerotia/kg and for low-ID plots was 2.0 sclerotia/kg. No other factor significantly affected ID of $S$. minor.

\section{DISCUSSION}

Peanut production systems generally include rotation to alternate crops to manage soilborne pathogens. The continuous cropping in these experiments may represent highly favorable conditions for disease development compared with typical farming systems.

Straw amendment in 3 years of continuous peanut had little influence on CBR incidence, AUDPC, or ID of C. parasiticum. Unusually high levels of CBR were seen in plots infested at low IDs in 1992. Levels of disease surpassed those in plots at highest IDs and ID was elevated correspondingly. This effect was not associated with straw amendment in plots nor was it consistent over the 3 years of the study.

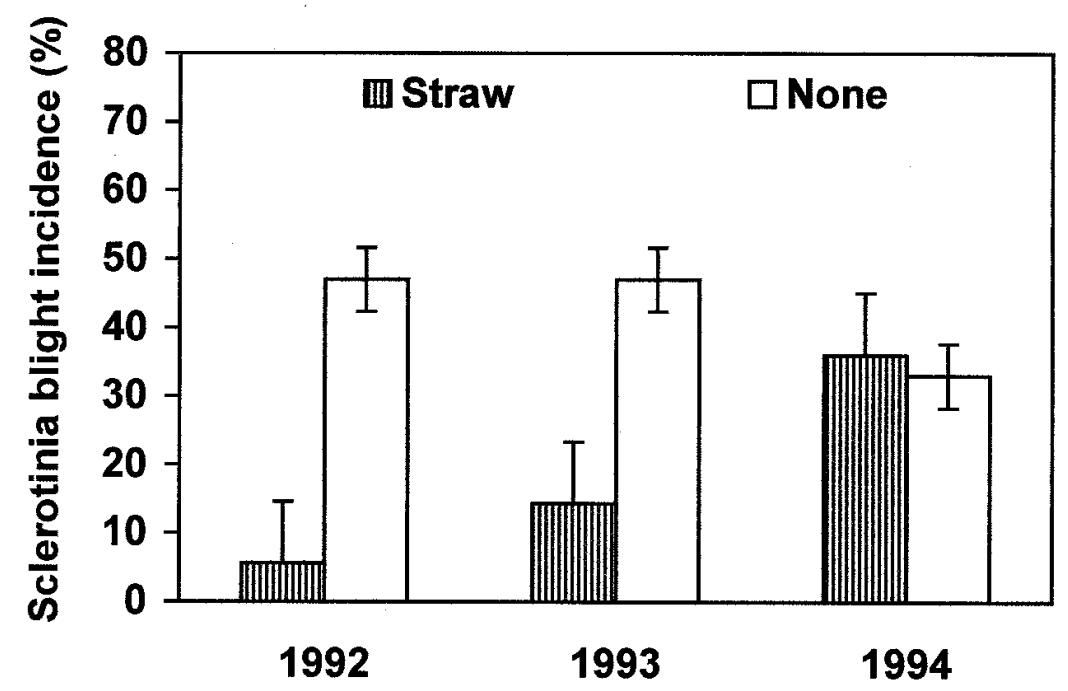

Fig. 7. Effects of wheat straw mulch on incidence of Sclerotinia blight of peanut. Mulch effects were significant in $1992(P \leq 0.0001)$ and $1993(P \leq 0.0003)$, but not in 1994 .

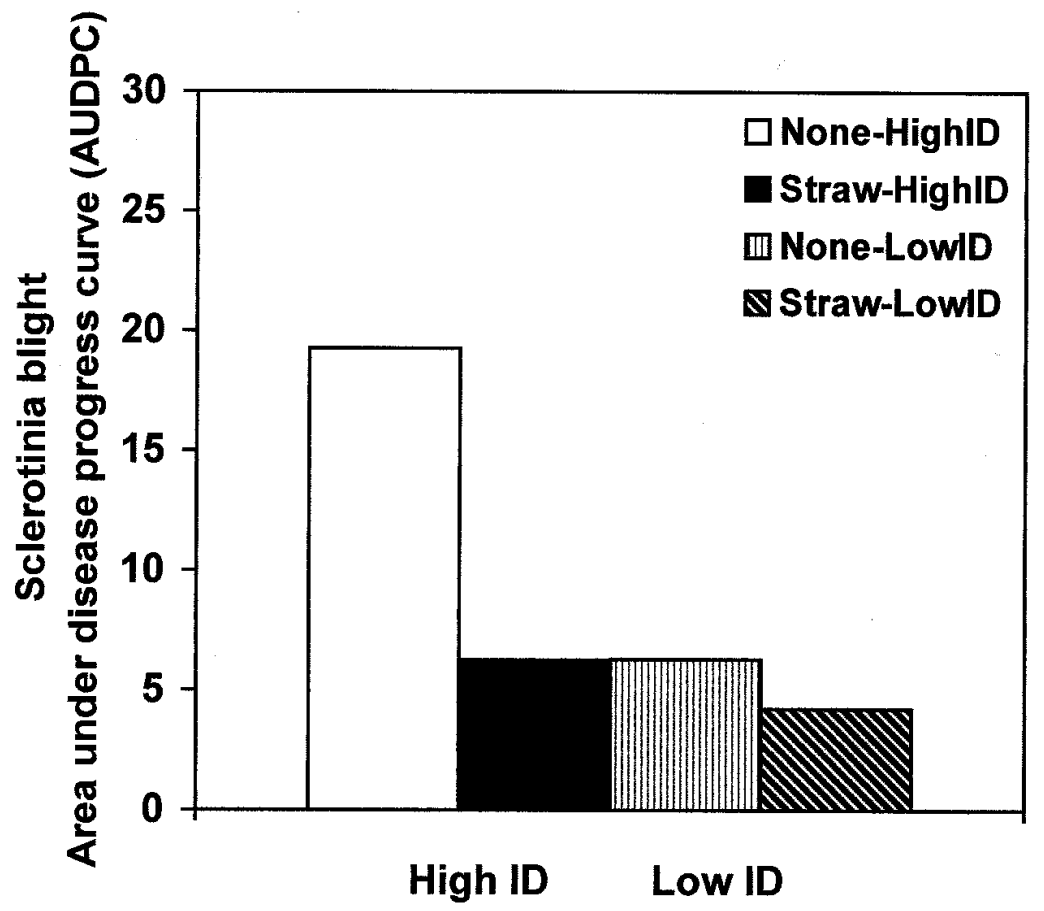

Fig. 8. Effects of wheat straw mulch and initial inoculum density (ID) on area under the disease progress curve (AUDPC) for Sclerotinia blight. Straw effects were significant at $P \leq 0.0097$ and ID effects at $P \leq 0.006$.

Black and Beute (7) found that soil samples from microplots infested at low IDs with a composite of several isolates tended to have large microsclerotia as opposed to high-ID plots, where microsclerotia were smaller. They found a clear relationship of increasing microsclerotia size with increased root rot severity. Factors other than ID and microsclerotia size which may limit disease severity are competition among propagules for infection sites and multiple infections (10). We expected that temperature-moderating organic residue would promote survival of $C$. parasiticum by limiting exposure to extreme temperatures and optimizing conditions for CBR development $(8,23,25)$. However, the straw mulch treatments did not result in increased disease or ID of $C$. parasiticum.

Southern stem rot incidence did not increase in response to straw amendment, regardless of ID or cultivar. Our findings corroborated those of other researchers, who found no consistent increases in southern stem rot in comparisons of conventional and reduced tillage practices $(12,20)$. Nevertheless, straw amendment was associated with higher numbers of sclerotia after 3 years of continuous peanut, particularly in plots with the cultivar NC 7. Final incidence and AUDPC in these plots were not different in the final year of the study from plots of the slightly more resistant NC 10C. This may suggest either that conditions in 1994 were not highly favorable for disease development or the possibility of a suppressive effect of continuous cultivation. It was notable that final ID of Sclerotium rolfsii was higher in plots initially infested at low ID and planted with NC 7 than in corresponding plots initially infested at high ID. We are unable to explain this effect. $S$. rolfsii effectively colonizes wheat straw as a substrate, and active mycelial growth and production of sclerotia was observed on straw in our studies. Sclerotia produced on wheat straw may differ in the amount of stored energy, size, and physiology, which may cause differences in pathogenicity compared to sclerotia produced on peanut tissues (13). Higher IDs in straw-amended plots did not result in higher incidence of southern stem rot; therefore, residue may make conditions unfavorable for infection, or may contribute to destruction of sclerotia and active mycelium $(34,35)$.

Straw amendment suppressed Sclerotinia blight in 1992 and 1993, but it had no effect on disease incidence in 1994. ID of Sclerotinia minor did not increase in straw-amended plots in comparison with nonamended plots. Suppressive effects of straw on Sclerotinia blight diminished in each year of continuous cultivation of peanut. Although ID was not assayed postseason in 1992 and 1993, our results indicate that there may be an ID threshold above which straw is no longer suppressive to $S$. minor. In addition, conditions in 1994 may 
have been more favorable for the development of Sclerotinia blight. Sclerotia survive best in moist soils $(-0.01$ to $-0.5 \mathrm{kPa})$, whereas saturated soil conditions $(0 \mathrm{kPa})$ maintain dormancy of sclerotia or encourage their disintegration $(1,17)$. Soil moisture in 1993 fluctuated over a wide range with repeated periods of soil saturation.

Altered microclimate conditions under residue coverage may influence survival and pathogenicity of sclerotia of $S$. minor, contributing to disease suppression. If alternating cycles of wet and dry conditions at the soil surface enhance sclerotial germination and infection by $S$. minor, straw amendment may maintain sclerotia in a dormant state by minimizing fluctuations in soil moisture $(21,36)$. In studies of biocontrol of sclerotial fungi, moist soil conditions and moderate temperatures, as observed under straw mulch, favor destruction of inoculum by soil microorganisms (2).

Plant residue may suppress Sclerotinia blight through several other mechanisms. Residue may present a physical barrier that reduces contact with the pathogen or the impacts of nontarget chemicals on $\mathrm{S}$. $\mathrm{mi}$ nor. For example, chlorothalonil, used routinely in our microplots to control Cercospora leaf spot, increases severity of Sclerotinia blight (15). Increased exposure of sclerotia to chlorothalonil in nonamended plots may have enhanced germination of sclerotia and disease incidence compared to plots amended with straw.

The presence of straw residue did not increase incidence of CBR, southern stem rot, or Sclerotinia blight in these microplot studies. On this basis, we may predict that these diseases would not increase and may decrease (in the case of Sclerotinia blight) with the implementation of reduced-tillage or other practices that add residues to the soil surface. Indeed, subsequent studies indicate that small grain mulches or cover crops may inhibit CBR development on peanut (32).

\section{ACKNOWLEDGMENTS}

We thank J. E. Hollowell and M. K. Beute of North Carolina State University and for their invaluable contributions to this research.

\section{LITERATURE CITED}

1. Abawi, G. S., and Grogan, R. G., and Duniway, J. M. 1985. Effect of water potential on survival of sclerotia of Sclerotinia minor in two California soils. Phytopathology 75:217-221.

2. Adams, P. B. 1990. The potential of mycoparasites for biological control of plant diseases. Annu. Rev. Phytopathol. 28:59-72.

3. Bailey, J. E. 1994. Peanut disease control. In:
Peanuts. Coop. Ext. Serv. Ext. Publ. AG-331. North Carolina State University, Raleigh.

4. Bailey, J. E., and Brune, P. D. 1997. Effect of crop pruning on Sclerotinia blight of peanut. Plant Dis. 81:990-995.

5. Barker, K. R., Daughtry, B. I., and Corbett, D. W. 1979. Equipment and techniques for establishing field microplots for the study of soilborne pathogens. J. Nematol. 11:106-108.

6. Black, M. C., and Beute, M. K. 1984. Effects of rotations with susceptible and resistant peanuts, soybeans, and corn on inoculum efficiency of Cylindrocladium crotalariae on peanuts. Plant Dis. 68:401-405.

7. Black, M. C., and Beute, M. K. 1984. Relationships among inoculum density, microsclerotium size, and inoculum efficiency of Cylindrocladium crotalariae causing root rot on peanuts. Phytopathology 74:1128-1132.

8. Black, M. C., Pataky, J. K., Beute, M. K., and Wynne, J. C. 1984. Management tactics that complement host resistance for control of Cylindrocladium black rot of peanuts. Peanut Sci. 11:70-73.

9. Bockus, W. W., and Shroyer, J. P. 1998. The impact of reduced tillage on soilborne plant pathogens. Annu. Rev. Phytopathol. 36:485500.

10. Cook, R. J., and Baker, K. F. 1983. The Nature and Practice of Biological Control of Plant Pathogens. American Phytopathological Society Press, St. Paul, MN.

11. Dow, R. L., Porter, D. M., and Powell, N. L. 1988. Effect of environmental factors on Sclerotinia minor and Sclerotinia blight of peanut. Phytopathology 78:672-676.

12. Grichar, W. J., and Smith, O. D. 1991. Effect of tillage systems on southern blight and pod yields of five runner peanut genotypes. Peanut Sci. 18:144-147.

13. Grogan, R. G., Sall, M. S., and Punja, A. K. 1980. Concepts for modeling root infections for soilborne fungi. Phytopathology 70:361363.

14. Harris, N. E., and Beute, M. K. 1982. Cylindrocladium crotalariae-induced periderm formation in taproot and fibrous roots of $\mathrm{Ara}$ chis hypogaea. Peanut Sci. 9:82:86.

15. Hau, F. C., and Beute, M. K. 1983. Effects of chlorothalonil on the virulence and physiology of a nontargeted pathogen, Sclerotinia minor. Phytopathology 73:475-479.

16. Hau, F. C., Beute, M. K., and Smith, T. 1982. Effect of soil $\mathrm{pH}$ and volatile stimulants from remoistened peanut leaves on germination of sclerotia of Sclerotinia minor. Plant Dis. 66:223-224.

17. Imolehin, E. D., Grogan, R. G., and Duniway, J. M. 1980. Effect of temperature and moisture tension on growth, sclerotial production, germination, and infection by Sclerotinia minor. Phytopathology 70:1153-1157.

18. Kokalis-Burelle, N., ed. Compendium of Peanut Diseases, 2nd ed. 1992. American Phytopathological Society Press, St. Paul, MN.

19. Mazzola, M., and Gu, Y. H. 2000. Impact of wheat cultivation on microbial communities from replant soils and apple growth in greenhouse trials. Phytopathology 90:114-119.

20. Minton, N. A., Csinos, A. S. Lynch, R. E., and Brenneman, T. B. 1991. Effects of two cropping and two tillage systems and pesticides on peanut pest management. Peanut Sci. 18:41-
46.

21. Patterson, C. L., and Grogan, R. G. 1988 Relationship of growth media and drying and of age of sclerotia to eruptive germination and infection by Sclerotinia minor. Plant Dis. 72:1046-1048.

22. Phipps, P. M., and Beute, M. K. 1976. An elutriation method for quantitative isolation of Cylindrocladium crotalariae microsclerotia from peanut field soil. Phytopathology 66:1255-1259.

23. Phipps, P. M., and Beute, M. K. 1977. Influence of soil temperature and moisture on the severity of Cylindrocladium black rot in peanut. Phytopathology 67:1104-1107.

24. Phipps, P. M., and Beute, M. K. 1977. Sensitivity of susceptible and resistant peanut cultivar to inoculum densities of Cylindrocla dium crotalariae microsclerotia in soil. Plant Dis. Rep. 61:300-303.

25. Phipps, P. M., and Beute, M. K. 1979. Population dynamics of Cylindrocladium crotalariae microsclerotia in naturally-infested soil. Phytopathology 69:240-243.

26. Porter, D. M., and Steele, J. L. 1983. Quantitative assay by elutriation of peanut field soil for sclerotia of Sclerotinia minor. Phytopathology 73:636-640.

27. Rothrock, C. S. 1992. Tillage systems and plant disease. Soil Sci. 154:308-315.

28. Rowe, R. C., and Beute, M. K. 1975. Variability in virulence of Cylindrocladium cro talariae isolates on peanut. Phytopathology 65:422-425.

29. Shaner, G., and Finney, P. E. 1977. The effect of nitrogen fertilization on expression of slow mildewing resistance in Knox wheat. Phytopathology 67:1051-1056.

30. Shetty, K. G., Subbarao, K. V., Huisman, O. C., and Hubbard, J. C. 2000. Mechanism of broccoli-mediated Verticillium wilt reduction in cauliflower. Phytopathology 90:305-310.

31. Shew, B. B., and Beute, M. K. 1984. Effects of crop management on the epidemiology of southern stem rot of peanut. Phytopathology 74:530-535.

32. Shew, B. B., and Beute, M. K. 1997. Suppression of Cylindrocladium black rot and Sclerotinia blight of peanut by winter cover crops in tilled and no-tilled microplots. (Abstr.) Phytopathology 87:589.

33. Sidebottom, J. R., and Beute, M. K. 1989 Control of Cylindrocladium black rot of peanut with cultural practices that modify soil temperature. Plant Dis. 73:672-676.

34. Smith, A. M. 1972. Drying and wetting of sclerotia promotes biological control of Sclerotium rolfsii Sacc. Soil Biol. Biochem. 4:119-123.

35. Smith, V. L., Jenkins, S. F., Punja, Z. K., and Benson, D. M. 1989. Survival of sclerotia of Sclerotium rolfsii: influence of sclerotial treatment and depth of burial. Soil Biol. Biochem. 21:627-632.

36. Wymore, L. A., and Lorbeer, J. W. 1987. Effect of cold treatment and drying on mycelial germination by sclerotia of Sclerotinia minor. Phytopathology 77:851-856.

37. Wynne, J. C., Beute, M. K., Bailey, J. E., and Mozingo, R. W. 1991. Registration of 'NC 10C' peanut. Crop Sci. 31:484.

38. Wynne, J. C., Mozingo, R. W., and Emery, D. A. 1979. Registration of NC 7 peanut (Reg. No. 22). Crop Sci. 19:563. 